\title{
O ENSINO RELIGIOSO NAS LEIS DE DIRETRIZES E BASES DA EDUCAÇÃO NACIONAL E OS EMBATES ENTRE RELIGIOSOS E LAICOS NO BRASIL
}

\author{
EDUCACIÓN RELIGIOSA EN LAS LEYES DE DIRECTRICES Y BASES DE LA \\ EDUCACIÓN NACIONAL Y LOS ENFRENTAMIENTOS ENTRE RELIGIOSOS Y \\ SECULARES EN BRASIL
}

\begin{abstract}
RELIGIOUS EDUCATION IN THE LAWS OF GUIDELINES AND BASES OF NATIONAL EDUCATION AND THE CLASHES BETWEEN RELIGIOUS AND SECULARS IN BRAZIL
\end{abstract}

Luize Gomes BUCHOLZ ${ }^{1}$ José Luis DERISSO ${ }^{2}$

RESUMO: Tomando como objeto o ensino religioso nas escolas públicas, o artigo busca fazer apontamentos nas leis de diretrizes e bases da educação nacional, desde a Lei $n^{\circ} 4024$ até Lei $\mathrm{n}^{\circ}$ 9394, respectivamente de 1961 e 1996, levando em consideração que a última foi alterada em 1997 pela Lei $n^{\circ}$ 9475, bem como os embates entre religiosos e laicos que compuseram o cenário de elaboração destas leis. Constata-se que as mudanças no ensino religioso operadas nos termos das leis, mas também nas formas de aplicação da disciplina nas escolas públicas, refletem as mudanças operadas na teologia e no pensamento católico no decorrer do século XX, uma vez que a Igreja Católica foi a grande força de sustentação dessa disciplina. Constata-se que o ensino religioso nas escolas públicas resulta de uma ânsia de legislar sobre matérias de fé, de foro íntimo, que resulta em pressão externa ao ambiente escolar que tende a comprometer os verdadeiros fins da educação escolar: garantir aos indivíduos acesso ao saber elaborado num ambiente democrático e comprometido com o respeito às diferenças e às liberdades de escolha.

Palavras-chave: Ensino religioso. Educação brasileira. Lei de diretrizes e bases da educação nacional.

RESUMEN: Tomando como objeto la educación religiosa en las escuelas públicas, el artículo busca tomar notas en las leyes de las directrices y bases de la educación nacional, desde la Ley No 4024 hasta la Ley No 9394, respectivamente de 1961 y 1996, teniendo en

\footnotetext{
${ }^{1}$ Universidade Estadual do Oeste do Paraná (Unoeste), Cascavel - PR - Brasil. Discente do programa de pósgraduação em Educação. ORCID: https://orcid.org/0000-0003-4603-4786. E-mail: luizebucholz@ gmail.com

${ }^{2}$ Universidade Estadual do Oeste do Paraná (Unoeste), Cascavel - PR - Brasil. Professor Adjunto do curso de Pedagogia e do Programa de Pós-Graduação em Educação Nível de Mestrado e Doutorado. ORCID: https://orcid.org/0000-0003-4044-4493.E-mail: joseluisderisso@yahoo.com.br
} 
cuenta que la última fue enmendada en 1997 por la Ley No 9475, así como los enfrentamientos entre religiosos y laicos que conforman el escenario de la redacción de estas leyes. Se observa que los cambios en la educación religiosa operados de acuerdo con las leyes, pero también en las formas de aplicación de la disciplina en las escuelas públicas, reflejan los cambios en la teología católica y el pensamiento durante el siglo XX, desde la Iglesia Católico fue la gran fuerza de apoyo de esta disciplina. Se observa que la educación religiosa en las escuelas públicas es el resultado del afán por legislar sobre cuestiones de fe, de foro íntimo, lo que se traduce en una presión externa al entorno escolar que tiende a comprometer los verdaderos fines de la educación escolar: garantizar a las personas acceso a los conocimientos elaborados en un entorno democrático y comprometidos con el respeto de las diferencias y libertades de elección.

PALABRAS CLAVE: Educación religiosa. Educación brasileña. Ley de directrices y bases de la educación nacional.

ABSTRACT: Taking as object the religious education in public schools, the article seeks to make notes in the laws of guidelines and bases of national education, from Law No. 4024 to Law No. 9394, respectively of 1961 and 1996, taking into account that the last was amended in 1997 by Law No. 9475, as well as the clashes between religious and lay people that made up the scenario of drafting these laws. It is observed that the changes in religious education operated in accordance with the laws, but also in the forms of application of discipline in public schools, reflect the changes in catholic theology and thought during the twentieth century, since the Church Catholic was the great force of support of this discipline. It is observed that religious education in public schools results from an eagerness to legislate on matters of faith, of intimate forum, which results in external pressure to the school environment that tends to compromise the true purposes of school education: to guarantee individuals access to knowledge elaborated in a democratic environment and committed to respect for differences and freedoms of choice.

KEYWORDS: Religious education; Brazilian education; Law of guidelines and bases of national education.

\section{Antecedentes: do regime de união Igreja e Estado aos embates do início da década de trinta do século $\mathrm{XX}$}

Ao abordar o ensino religioso nas escolas públicas brasileiras, o artigo enfoca as transformações que se operaram no plano legal, bem como os embates políticos e ideológicos entre religiosos e laicos em torno deste tema. O recorte temporal é marcado pelos contextos de elaboração das leis de diretrizes e bases da educação no Brasil, a saber: as leis 4024/61 e 9495/96, e a emenda ao artigo 33 desta última feita pela Lei 9475/97. Porém, uma breve 
retrospectiva assinalando o nível de hegemonização da religião católica na educação brasileira deve contribuir para a localização histórica de nosso objeto.

O regime de união entre Estado e Igreja Católica perdurou no Brasil desde o início da colonização portuguesa até a Proclamação da República em 1889, passando pelo período monárquico inaugurado com Independência do Brasil em 1822. Neste período as tensões entre o episcopado brasileiro e o poder civil chegaram ao ápice na década de 1870 com as prisões de dois bispos católicos que se recusaram a submeter-se às leis do Império que contrariavam as orientações provindas de Roma.

Nestes quase quatro séculos, a religião encontra-se presente

[...] desde as escolas de primeiras letras até as de grau mais elevado, a religião estava presente na escola por meio da catequese e da História Sagrada como uma decorrência do regime de união entre Igreja e Estado (DERISSO, 2006, p. 20).

Após a Proclamação da República, a Constituição de 1891 estabelece a separação entre Igreja e Estado retirando da Igreja Católica suas prerrogativas na educação, no controle dos cemitérios, dos registros de nascimento e casamento e cortando as fontes de financiamento provindas de verbas públicas.

No plano educacional, nas primeiras décadas da nascente república, ocorrem várias tentativas de organizar a educação escolar, com destaque para as reformas educacionais que ocorrem no âmbito de alguns dos principais estados da federação. Porém, no geral, o saldo é muito pequeno.

Após a Revolução de 1930, a educação escolar será demandada pelas novas necessidades econômicas pautadas nas demandas da sociedade urbana e industrial. A publicação do Manifesto dos Pioneiros da Educação em 1932 é emblemática desse período, por um lado porque explicita as pretensões dos renovadores - pioneiros das reformas educacionais promovidas nos estados - para com a nova constituição em via de elaboração, e por outro porque marca um momento agudo dos embates entre católicos e liberais (laicos).

Além da influência ideológica da Igreja Católica que norteava a educação brasileira, é importante considerar que esta também era marcada por uma elitização extrema, pois o índice de analfabetismo entre pessoas maiores de quinze anos beirava sessenta e cinco por cento e o acesso aos níveis posteriores ao ensino primário, de quatro anos de duração, ocorria por meio de um "pente fino" que favorecia as classes mais abastadas.

As pretensões dos "pioneiros" iam no sentido de superar as fragrantes desigualdades de acesso e de criar um sistema nacional de educação. 
As proposições básicas do Manifesto dos Pioneiros da Escola Nova eram: obrigatoriedade e gratuidade do ensino, o que implicava na responsabilidade do Estado pela implantação de um sistema de ensino; articulação do ensino com as necessidades da nova realidade criada pela sociedade industrial; escola única para todos e sem distinção de sexo; e laicidade. Estas proposições refletiam a existência de dois componentes que, segundo o historiador da educação Jorge Nagle, animavam os educadores naquele momento, a saber: o "entusiasmo pela educação" e o "otimismo pedagógico" (DERISSO, 2006, p. 42).

O embate com os católicos ocorre em função da centralidade na educação escolar que os pioneiros atribuem ao Estado. Porém, o componente que mais importa para a discussão no presente artigo é o embate em torno da questão da laicidade e mais particularmente do ensino religioso nas escolas públicas. Acerca dessa questão a posição do Manifesto dos Pioneiros é a que segue:

A laicidade, que coloca o ambiente escolar acima de crenças e disputas religiosas, alheio a todo o dogmatismo sectário, subtrai o educando, respeitando-lhe a integridade da personalidade em formação, à pressão perturbadora da escola quando utilizada como instrumento de propaganda de seitas e doutrinas (AZEVEDO, 1960, p. 155).

A partir da compreensão histórica dos embates entre laicos e católicos, o tópico seguinte analisa as leis de diretrizes e bases da educação nacional no Brasil no tocante à disciplina Ensino Religioso nas escolas públicas, articulando-as aos seus respectivos contextos históricos.

\section{A elaboração da Lei no 4.024/61e o tratamento dado ao Ensino Religioso}

O debate principal nos anos que precedem a instituição da primeira Lei de Diretrizes e Bases da Educação Nacional, em 1961, girava em torno de dois grupos, os defensores da escola pública, designados liberais por Cury (1986), e o grupo daqueles que se opunham ao protagonismo do Estado na educação, constituído principalmente pelos católicos, mas também por proprietários de escolas ${ }^{3}$.

Cunha e Góes (1991) situam os anos de 1960 como anos de crise econômica, social e política. Tal contexto leva os educadores a "botar a cabeça para fora da sala de aula para olhar e estudar o mundo" (CUNHA; GOÉS, 1991, p. 11) e é caracterizado pelas discussões acerca

\footnotetext{
${ }^{3}$ Os católicos, nesse período, não defendem diretamente a privatização, se o defendem não o fazem com o fim de mercantilização da educação, mas por conveniência própria, em função de um objetivo ideológico/religioso. Sua aliança com privatistas pró-mercantilização pode-se dizer que é apenas tática.
} 
da Lei de Diretrizes e Bases da Educação Nacional, tanto no Congresso Nacional como no campo educacional, com repercussões na imprensa da época.

Além das manifestações de estudantes e operários através da UNE e dos sindicatos, a questão aparecia nos jornais de grande circulação como $\mathrm{O}$ Estado de São Paulo, mas ficou registrado, sobretudo, nas páginas de três periódicos: a Revista Brasileira de Estudos Pedagógicos e Revista Anhembi, defendendo a escola pública; e a revista Vozes de Petrópolis, de orientação católica, defendendo as prerrogativas das escolas particulares. (DERISSO, 2006, p. 48).

Naquele contexto, os católicos sustentavam que os pais deveriam ter "liberdade de escolha" no modo pelo qual os filhos deveriam ser educados, e que o Estado deveria prover com recursos financeiros os estudos daqueles que optassem por escolas não estatais, como as escolas confessionais católicas que constituíam a maioria destas. Tal reivindicação se chocava com o modelo de escola republicana sustentado pelos signatários do "Manifesto da Educação Nova de 1932" e do manifesto "Mais uma vez convocados" de $1959^{4}$.

A reivindicação católica de subsídios do Estado para as escolas confessionais sustentava-se no Código de Direito Canônico de 1917 e na Carta Encíclica Divini IIlius Magistri do Papa Pio XI, publicada em 31 de dezembro de 1929, por meio da qual o pontífice afirmava que para a educação concorrem por um lado a família e a sociedade civil, instituições apresentadas como de ordem natural, e por outro a Igreja, concebida como de ordem sobrenatural. Este documento concebe como direito e dever da Igreja a educação dos fiéis, condena, entre outras coisas, o socialismo e a coeducação, e apela aos pais para que zelem pela educação de seus filhos optando por uma educação de bases católicas, conforme se aprende da passagem que se segue:

[...] a escola chamada neutra ou laica, donde é excluída a religião, é contrária aos princípios fundamentais da educação. De resto uma tal escola é praticamente impossível, porque de fato torna-se irreligiosa. Não ocorre repetir aqui quanto acerca deste assunto disseram os Nossos Predecessores, nomeadamente Pio IX e Leão XIII, em cujos tempos começou particularmente a dominar o laicismo na escola pública. Nós renovamos e confirmamos as suas declarações, (...) e juntamente as prescrições dos Sagrados Cânones pelas quais é proibida aos jovens católicos a frequiência de escolas acatólicas, neutras ou mistas, isto é, daquelas que são abertas indiferentemente para católicos e não católicos, sem distinção, e só pode tolerar-se tal frequiência unicamente em determinadas circunstâncias de lugar

\footnotetext{
${ }^{4}$ Em janeiro de 1959, frente aos embates da elaboração da Lei de Diretrizes e Bases da Educação Nacional, foi publicado o "Manifesto dos Educadores: Mais uma Vez Convocados", também elaborado por Fernando de Azevedo, mas que contou com a assinatura de mais de 200 educadores. Texto que novamente carrega as reflexões acerca da gratuidade, obrigatoriedade e laicidade do ensino.
} 
e de tempo, e sob especiais cautelas de que é juiz o Ordinário. (PIO XI, 1929, grifos nosso).

Segundo Saviani (2006), a elaboração da lei $n^{\circ} 4024 / 61$ ocorreu por exigência da Constituição Federal de 1946, que concedia à União a responsabilidade de fixar as diretrizes da educação nacional. O percurso de aprovação do projeto da Lei de Diretrizes e Bases da Educação Nacional é marcado por discussões e resistências, e chega à aprovação com grandes alterações em comparação ao projeto original.

[...] a fase de chegada à versão final correspondeu ao momento em que a discussão das questões educacionais extravasou do seu âmbito específico para empolgar a opinião pública em geral. Entram em cena, como já se disse, os "partidos ideológicos". A igreja mobiliza todos os seus quadros na defesa de determinada posição que consultava os interesses privatistas. A imprensa mobiliza-se, posicionando-se alguns órgãos a favor da escola privada e outros a favor da escola pública (SAVIANI, 2006, p. 42).

Para se ter uma dimensão aproximada da polarização a que se refere Saviani convém observar que desde a entrega do projeto de lei pelo Ministro da Educação Clemente Mariani ao Presidente Dutra - a seguir encaminhado ao Congresso Nacional -, em outubro de 1948, até a aprovação da Lei n4024/61, Lei de Diretrizes da Educação Nacional (LDB), transcorre treze anos de intensos e acirrados debates, marcados por momentos em que a razão era facilmente substituída pela paixão movida pela vontade de vencer o oponente a qualquer custo. Nestes momentos, intenções e posições não explicitadas nos documentos eram atribuídas aos interlocutores, como se pode apreender do fragmento abaixo do documento intitulado "Memorial do Bispos", endereçado ao Presidente da República no ano de 1957:

A idéia de que todo o ensino deve emanar do Estado não é nova, mas é certamente alheia à tradição brasileira e à mesma Constituição do País.

$\mathrm{Na}$ "República" de Platão, na "Civitas Solis" de Campanella, na "Nova Atlantis" de Bacon, não é difícil descobrirem-se antecedentes, mais ou menos definidos, ainda que nascidos de divagações de fantasia, para o princípio que se pretende impor ao nosso país. Trágico, porém, é que, fora das concepções utópicas dos filósofos, a idéia, cuja realização se persegue, entre nós, com tal pertinácia, é, já hoje, um dos postulados do socialismo militante e, em têrmos de execução, preparação necessária à gradativa implantação dêste. [...]

Não é difícil apreender o caráter sofista do discurso no documento - sofista no sentido pejorativo, de ânsia de vencer a discussão sem se importar com a forma: a ideia existe há dois mil e quinhentos anos, movida por estimulação fantasiosa, mas na medida em que é apropriada pelos socialistas torna-se a marca destes, de modo que todos aqueles que a sustentaram serão também socialistas. Como o Professor Anísio Teixeira: 
Tal é o que prega abertamente entre nós o professor Anísio Teixeira, com a qualidade e responsabilidade de diretor do Instituto Nacional de Estudos Pedagógicos (INEP) e de secretário-geral da Campanha Nacional de Aperfeiçoamento do Pessoal de Nível Superior (CAPES). Ainda que inculque não advogar "o monopólio da educação pelo Estado" (Educação não é privilégio, Rio de janeiro, 1957, p. 114), - o que não admira, porque o socialismo, em suas correntes predominantes não é estatista - o professor Anísio Teixeira espera da escola pública ou comum, que tão ardentemente preconiza, os mesmos resultados pré-revolucionários, previstos, com ansiosa expectativa, pela doutrina socialista (SCHERER, 1958, p. 362-364, grifos nossos).

Ou seja, o professor Anísio Teixeira afirma em artigo de grande repercussão no meio educacional que não advoga o monopólio da educação pelo Estado, e mesmo que, em várias oportunidades, tenha afirmado não ser comunista, os adversários da escola pública a ele atribuem posições contrárias às declaradas, posições estas que não são suas. E assim, do mesmo modo, tratam o projeto de Lei sustentado pelo Ministro Clemente Mariani, cujo nome também nunca figurou entre os defensores do socialismo.

Neste cenário de pouca racionalidade e muita emoção, no qual os interesses empresariais apoiam-se nos argumentos ideológicos dos católicos, a Lei nº 4024/61 estabelece sobre o ensino religioso:

Art. 97. O ensino religioso constitui disciplina dos horários das escolas oficiais, é de matrícula facultativa, e será ministrado sem ônus para os poderes públicos, de acôrdo com a confissão religiosa do aluno, manifestada por êle, se fôr capaz, ou pelo seu representante legal ou responsável.

$\S 1^{\circ}$ A formação de classe para o ensino religioso independe de número mínimo de alunos.

$\S 2^{\circ} \mathrm{O}$ registro dos professores de ensino religioso será realizado perante a autoridade religiosa respectiva (BRASIL, 1961).

Ou seja, para esta disciplina em particular o professor ficaria desobrigado de responder aos critérios legais para o pertencimento ao magistério oficial, bastando a indicação da autoridade religiosa. E a disciplina mesmo que facultativa ocupa espaço no horário normal, deixando ociosos e certamente visíveis as crianças que forem dispensadas de cursá-la.

Porém, as vitórias do setor empresarial e da Igreja foram muito além, pois em nome da propalada "liberdade de ensino", a Lei abriu brecha para que verbas públicas fossem destinadas às escolas particulares:

Artigo $3^{\circ}$ - O direito à educação é assegurado:

I - pela obrigação do poder público e pela liberdade da iniciativa particular de ministrarem o ensino em todos os graus, na forma da lei em vigor; 
II- pela obrigação do Estado de fornecer recursos indispensáveis para que a família e, na falta desta, os demais membros da sociedade se desobriguem dos encargos da educação, quando provada a insuficiência de meios, de modo que sejam asseguradas iguais oportunidades a todos.

A interpretação da Lei que possibilita a instituição de subsídios às instituições privadas seria então a combinação da liberdade de ensino (por exemplo, o direito de uma família sem recursos pleitear uma educação católica para seus filhos) e obrigação do Estado de fornecer os recursos. Mas obviamente que a questão não tende a se colocar juridicamente num âmbito individual, porém a Igreja Católica e os grandes empresários conseguiram fazer valer esta brecha de modo a favorecê-los, por meio de bolsas de ensino. Sendo assim, a Igreja é duplamente atendida nos seus pleitos: a escola pública se obriga a fornecer ensino religioso e o Estado a subsidiar as escolas confessionais.

A primeira LDB foi gestada antes do golpe militar de 1964, após o qual a legislação educacional assume características mais tecnicistas e mais explicitamente vinculadas aos interesses do capital. A Lei ${ }^{\circ} 5692$ de 1971 procede a uma reforma do ensino por meio da qual o primeiro grau se estende por oito anos e o segundo grau, de três anos de duração, ganha contornos de ensino de técnico. Porém, dois anos antes da 5692/71, o Decreto-Lei no 869, de 12 de setembro de 1969 inclui "Educação Moral e Cívica como disciplina obrigatória, nas escolas de todos os graus e modalidades, dos sistemas de ensino no País". No artigo $2^{\circ}$ desta lei pode-se ler que

A Educação Moral e Cívica, apoiando-se nas tradições nacionais, tem como finalidade: a defesa do princípio democrático, através da preservação do espírito religioso, da dignidade da pessoa humana e do amor à liberdade com responsabilidade, sob a inspiração de Deus; (Brasil, 1969, grifos nossos).

Após o quê o Conselho Federal de Educação, por meio do Parecer n $94^{\circ} / 71$, esclarece qual o fundamento da moral objetivada pela disciplina:

[...] se as raízes da Moral e da Religião de tal forma se entrelaçam, dentro da alma humana, como proceder-se a uma dissociação radical entre as duas?

Surge aqui $[. .$.$] a decorrência de que o fundamento religioso que, segundo o$ que se depreende do Decreto-Lei $n^{\circ} .869 / 69$, deve estar subjacente à Moral a ser ensinada na Educação Moral e Cívica, será tomada da chamada Religião Natural (BRASIL, 1971).

Este mesmo parecer, segundo Derisso (2006, p. 50), justifica a menção a Deus no preâmbulo da Constituição e o Ensino Religioso nas escolas públicas sob o argumento de tratar-se de manifestação de respeito a convicção religiosa da grande maioria do povo 
brasileiro, sem que tal fato constitua em privilegio porque que a constituição garante a liberdade religiosa no País. Porém, mesmo garantindo a liberdade de consciência, de adoção de religião ou de filosofia, a simples menção de Deus significa, no entendimento dos autores deste artigo, atribuir às chamadas "religiões de Deus" um privilégio simbólico não atribuído a outras crenças ou concepções de mundo.

\section{A Lei no 9.394/96 e os conflitos que levaram à Lei nº 9475/97}

Com a promulgação da Constituição de 1988, inicia-se no Congresso o processo de discussão de uma nova lei de diretrizes da educação, o que, assim como no processo que culminou na Lei 4024/61, foi concomitante com o processo de discussão nos setores organizados da sociedade, particularmente os diretamente ligados ao campo educacional: No âmbito sindical e intelectual, particularmente os ligados à educação pública, a discussão versou com maior prioridade sobre as responsabilidades do Estado para com a educação, visando estabelecer a destinação de recursos e estabelecimento de metas no sentido de atingir a universalização da educação básica e de democratizar (lê-se ampliar) o acesso ao ensino superior; no âmbito das escolas privadas a pressão ia, assim como em 1961, no sentido de pleitear maior acesso aos recursos públicos; já no âmbito das escolas confessionais, além da questão do acesso aos recursos públicos, a questão do ensino religioso voltou à tona e implicou em mudança no enfoque dos objetos de ensino e em responsabilização do Estado pelos custos que até então repousavam sobre as "autoridades religiosas".

A Lei estabelecia relativamente à disciplina em questão, no momento de sua promulgação em 1996:

Art. 33. O ensino religioso, de matrícula facultativa, constitui disciplina dos horários normais das escolas públicas de ensino fundamental, sendo oferecido, sem ônus para os cofres públicos, de acordo com as preferências manifestadas pelos alunos ou por seus responsáveis, em caráter:

I - confessional, de acordo com a opção religiosa do aluno ou do responsável, ministrado por professores ou orientadores religiosos preparados e credenciados pelas respectivas igrejas ou entidades religiosas; ou

II - interconfessional, resultante de acordo entre as diversas entidades religiosas, que se responsabilizarão pela elaboração do respectivo programa. (BRASIL, 1996).

Percebe-se que o artigo não apresenta inovação no tocante ao papel dos sistemas de ensino e do Estado que continuam cedendo tempo e espaço para efetivação da disciplina, a não ser pelo inciso II que passa a prever a possibilidade de articulação entre confissões 
religiosas para estabelecer e efetivar um ensino denominado "interconfessional", uma possibilidade que seria inimaginável para a Igreja Católica antes de sua reorientação no e a partir do Concílio do Vaticano II (1962-1965), momento em que ocorre uma inflexão desta instituição que poderia ser definida de uma maior abertura para o mundo e adequação às transformações da chamada modernidade, cujas manifestações haviam sido duramente criticadas por Roma, conforme podemos apreender de dois documentos emblemáticos: a Encíclica Quanta Cura, do Papa Pio IX, e a Encíclica Pascendi Dominici Gregis, do Papa Pio X, respectivamente de 1864 e 1907.

Importante recordar que até o Concílio Vaticano II a posição oficial da Igreja Católica estabelecia a proibição "aos jovens católicos a frequência de escolas acatólicas, neutras ou mistas, isto é, daquelas que são abertas indiferentemente para católicos e não católicos" (PIO XI, 1929) e coerente com tal posição, os católicos brasileiros defendiam que o Estado subsidiasse por meio de bolsas de estudo os alunos católicos para que os mesmos frequentassem escolas católicas.

Após o Concílio, a posição da Igreja mudou radicalmente acerca do papel do Estado na educação e sobre a pluralidade cultural na sociedade moderna:

[...] a Igreja louva aquelas autoridades e sociedades civis que, tendo em conta o pluralismo da sociedade moderna e atendendo à justa liberdade religiosa, ajudam as famílias para que a educação dos filhos possa ser dada em todas as escolas segundo os princípios morais e religiosos das mesmas famílias (PAULO VI, 1965, p. 7).

Com relação aos custos da disciplina, mantém-se em 1996 a mesma formulação contida na LDB de 1961, ou seja, os custos não poderiam onerar os cofres públicos. Talvez tenha sido esta formulação a responsável pela insatisfação do "lobby" religioso que se constitui no processo de elaboração da LDB, e que, diga-se de passagem, manteve-se organizado após a promulgação da Lei 9495/96.

Essa redação não agradou várias autoridades religiosas, em especial as católicas, cujo objetivo inicial era pressionar a presidência da República a fazer uso do seu direito de veto. O próprio Executivo assumiu, então, o compromisso de alterar o art. 33 mediante projeto de lei, daí resultando a lei $n^{\circ}$ 9.475/97 (CURY, 2004, p. 185).

Entre as organizações religiosas que compuseram o "lobby" destacam-se a Confederação Nacional dos Bispos do Brasil (CNBB), o Conselho Nacional das Igrejas Cristãs (CONIC), a Associação de Educação Católica (AEC), a Associação de Professores de Ensino Religioso do Distrito Federal (ASPER), o Fórum Nacional Permanente do Ensino 
Religioso (FONAPER) e as Coordenações Estaduais de Ensino Religioso. E a pressão se fez sentir, de modo que

Nem mesmo tinha secado a tinta da assinatura do Presidente Fernando Henrique Cardoso no documento em que promulgou a segunda LDB, em dezembro de 1996, ele próprio manifestou a intenção de promover a mudança do artigo 33, que tratava do Ensino Religioso nas escolas públicas. O presidente se referiu, diretamente, ao fim da proibição de uso de recursos públicos para essa disciplina. $\mathrm{O}$ apelo foi eficaz, pois o projeto do MEC se somou a dois outros, de prestativos deputados interessados em oferecer serviço aos promotores da segunda visita do papa João Paulo II ao Brasil. Um projeto substitutivo foi elaborado pelo deputado Padre Roque, que, tramitando em regime de urgência, foi aprovado por voto de lideranças. (CUNHA, 2009, p. 411)

Este substitutivo se converteu, uma vez aprovado, na Lei 9745/97 que altera o Artigo 33 para:

Art. 33. O ensino religioso, de matrícula facultativa, é parte integrante da formação básica do cidadão e constitui disciplina dos horários normais das escolas públicas de ensino fundamental, assegurado o respeito à diversidade cultural religiosa do Brasil, vedadas quaisquer formas de proselitismo.

$\S 1^{\circ}$ Os sistemas de ensino regulamentarão os procedimentos para a definição dos conteúdos do ensino religioso e estabelecerão as normas para a habilitação e admissão dos professores.

$\S 2^{\circ}$ Os sistemas de ensino ouvirão entidade civil, constituída pelas diferentes denominações religiosas, para a definição dos conteúdos do ensino religioso (BRASIL, 1997).

Primeiro fato a se destacar é o de que a proibição de que os custos da disciplina onerem os cofres públicos desaparece. Fato que simboliza por si só uma importante vitória do "lobby" religioso. Mas outro fato tão importante quanto o primeiro é que ao mesmo tempo em que a Lei institui o ensino religioso como disciplina facultativa, a define como "parte integrante da formação básica", encerrando-se assim uma contradição de cuja ambiguidade os defensores da obrigatoriedade da frequência tentarão se aproveitar, sem sucesso.

Acerca da definição segundo a qual o ensino religioso seria integrante da formação básica, Cunha (2009, p. 411) disserta ser esta uma suposição de que a formação dos alunos seria "insuficiente ou defeituosa", caso, por opção da família ou impossibilidade de acesso, estes mesmos alunos não frequentassem a disciplina ou recebessem a instrução correspondente a ela em algum momento da vida.

Quanto ao seu caráter confessional, este parece ficar comprometido pelo veto ao proselitismo, mas mesmo assim este formato se manteve em alguns sistemas de ensino, a exemplo do Estado do Rio de Janeiro que realizou concurso para professores de Ensino 
Religioso em duas fases: na primeira o Estado seleciona os aprovados em conhecimentos gerais de educação; na segunda as autoridades religiosas credenciadas, respeitando cotas préestabelecidas, escolhem entre os aprovados aqueles que passarão a compor o corpo de professores de cada religião. ${ }^{5}$

No entanto, no estado de São Paulo a orientação foi no sentido de acolher os termos da Lei 9475/97 e o Parecer do Conselho Federal de Educação:

Até aquele momento o Conselho Federal de Educação havia emitido dois pareceres sobre o ensino religioso. No primeiro, de $n^{\circ}$. 05/97, indica que é da competência da escola definir o horário e o espaço da disciplina e das Igrejas, individualmente ou associadas, o cadastramento dos professores, para atender os matriculados - esse parecer foi anterior ao substitutivo $\mathrm{n}^{\circ}$ 9475/97, portanto ainda à luz do Artigo 33 da Lei nº 9394/96 -; no segundo, o de $n^{\circ}$ 97/99, diz que a fixação de "conteúdos e habilitações e admissão de professores ficam a cargo dos diferentes sistemas de ensino" [...] (DERISSO, 2012, p. 196).

Neste sentido, implementa-se neste estado um ensino religioso não confessional e implementado pela Secretaria de Educação após uma Audiência Pública, ministrado por professores vinculados à esta rede de ensino, preferencialmente com formação em História. A elaboração de materiais de apoio passou por dois momentos, em 2001 a Secretaria de Educação editou um livreto de apoio aos professores com orientação ecumênica cristã, nos moldes dos "Parâmetros Curriculares do Ensino Religioso" produzido pelo Fórum Nacional Permanente do Ensino Religioso (FONAPER), uma articulação de professores de ensino religioso que cumpriu importante papel na atividade de "lobby" na aprovação da Lei 9475/97; meses depois o mesmo órgão governamental iniciou a edição de cinco cadernos sequenciais com a mesma destinação do primeiro, porém com orientação multicultural.

Percebe-se, assim, que os termos da lei não impediram que a disciplina fosse ministrada em diferentes sistemas ensino do país de diferentes formas, atendendo as pressões de grupos políticos e religiosos. E com o concurso das verbas públicas.

${ }^{5}$ A Lei $n^{\circ} 3459$ de 14 de setembro de 2000 dispôs sobre o ensino religioso confessional nas escolas da rede pública de ensino do Estado do Rio de Janeiro, estabelecendo, em conflito com a Lei 9475/97, que os professores da disciplina deveriam ter registro no MEC e pertencessem preferencialmente aos quadros do Magistério Público Estadual, porém, a palavra final na escolha destes caberia às autoridades religiosas competentes, que poderiam destituí-los em caso de declínio de fé. Estabelece também que o conteúdo da disciplina seria atribuição das autoridades religiosas. O edital do concurso para professores, publicado em 16 de outubro de 2003, previa a contratação de 500 professores, sendo 342 católicos, 132 evangélicos e 26 de outros credos. Esta composição reflete um estudo estatístico realizado pela Comissão de Planejamento do Ensino Religioso Confessional. 


\section{Considerações Finais}

Apesar da evidência histórica de que os embates entre religiosos e laicos foram bastante acirrados no plano ideológico, outras questões permearam a política e a história da educação escolar brasileira durante o século XX. O projeto modernizador afirmado pelos revolucionários de 1930 não foi rejeitado pelos católicos na constituinte de 1934 e nem a política de expansão industrial foi colocada em questão no processo de elaboração da LDB 1961.

O governo provisório de Getúlio Vargas (1930/34) e o Estado Novo (1937/45), fizeram concessões à religião, mais particularmente à Igreja Católica, com fỉm de ampliarem suas respectivas bases políticas de sustentação; Em 1961, os embates ideológicos na elaboração da LDB situavam-se temporalmente no contexto da Guerra Fria, mas a despeito das acusações dos conservadores católicos, o campo oponente por estes nomeados de comunistas não avança além dos limites da democracia representativa, certamente com mais sensibilidade social e vontade de corrigir algumas das grandes distorções no sentido de saudar uma dívida social que advinha do período colonial. Mas sem, no entanto, situar-se na oposição ao do capitalismo.

Pode-se afirmar que o curso do desenvolvimento capitalista do Brasil nunca esteve em questão nos embates entre católicos e laicos, assim como do ponto de vista dos representantes do Estado, o conservadorismo pela permanência do elo com a Igreja Católica coexiste ao lado da ânsia pela modernização da sociedade brasileira e da industrialização do país.

O Ensino Religioso nas escolas públicas assume na história da educação escolar brasileira do século XX um forte caráter simbólico para a Igreja Católica. A disciplina, ao lado de algumas outras concessões formais (proibição do divórcio, criminalização do suicídio, a menção a Deus no preâmbulo da Constituição, entre outras) se constitui em moeda de troca do Estado para com a Igreja, com o fim de manutenção da coerção social.

O debate sobre o caráter desta disciplina se atualiza com o posicionamento do STF em 2017 no sentido de retomar seu caráter confessional, em flagrante contradição com o veto ao proselitismo presente na Lei $\mathrm{n}^{\circ}$ 9475/97. Porém, com relação ao papel desempenhado historicamente pelos legisladores brasileiros acerca dessa questão, cabe assinalar a existência de uma permanente resistência em separar as questões de fé, que deveriam situar-se no plano do fórum íntimo, da questão da cidadania e da democracia.

Do ponto de vista dos autores deste artigo, a questão não se encerra na forma da aplicação da disciplina, nos seus objetos de ensino ou em torno do ônus para os cofres 
públicos, mas na definição dos fins da educação, particularmente das necessidades e potencialidades da educação escolar. Ou seja, para garantir rigorosamente o cumprimento de sua função de garantir aos indivíduos, sobretudo às gerações mais novas, o acesso ao conhecimento socialmente produzido e historicamente acumulado, a escola não deveria cercear ou impor objetos de ensino com o fim de satisfazer interesses de grupos de pressão, quer econômicos, políticos ou religiosos. Contrariamente, deveria selecionar e organizar os objetos de ensino com o concurso dos educadores no interior das escolas e dos sistemas de ensino, num ambiente democrático, independente das preferências religiosas predominantes, e somente levar em contar tal fato quando o fim for o de promover o respeito e a convivência.

\section{REFERENCIAS}

AZEVEDO, Fernando. Manifesto dos Pioneiros da Escola Nova. In: Revista Brasileira de Estudos Pedagógicos. Brasília: INEP, v. XXXIV, n. 79, jul./set. 1960.

BRASIL, República Federativa do. Lei n. 9.475/97, de 22 de julho de 1997. Diário Oficial da União, Brasília, 23 jul. 1997a. Disponível em:

http://www.planalto.gov.br/ccivil_03/leis/L9475.htm. Acesso em: jan. 2020.

BRASIL. Parecer n. 05/97 do Conselho Nacional de Educação. Relator: João Antônio Cabral de Monlevade e José Arthur Giannotti. Brasília, DF, 11 de março de 1997b.

BRASIL. Lei n. 9.394, de 20 de dezembro de 1996. LDB: Lei das Diretrizes e Bases da Educação nacional. Estabelece as diretrizes e bases da educação nacional. Diário Oficial da União, Brasília, DF, 23 dez. 1996. Disponível em:

http://www.planalto.gov.br/ccivil_03/leis/19394.htm. Acesso em: jan. 2020.

BRASIL. Constituição da República Federativa do Brasil de 1988. Diário Oficial da União, Brasília, DF, 5 out. 1988. Disponível em:

http://www.planalto.gov.br/ccivil_03/constituicao/constituicao.htm. Acesso em: 28 abr 2011.

BRASIL. Parecer n. 94/71 do Conselho Federal de Educação, de 04 de fevereiro de 1971

BRASIL. Lei n. 869, de 12 de setembro de 1969. Dispõe sobre a inclusão da Educação Moral e Cívica como disciplina obrigatória. Diário Oficial da união, Brasília, DF, 15 set. 1969. Disponível em: http://www.planalto.gov.br/ccivil_03/Decreto-Lei/1965-1988/Del0869.htm. Acesso em: jan. 2020.

BRASIL. Lei n. 4.024, de 20 de dezembro de 1961. Fixa as diretrizes e bases da educação nacional. Lei de Diretrizes e Bases da Educação-LDB. Diário Oficial da União, Brasília, DF, 27 dez. 1961. Disponível em: http://www.planalto.gov.br/ccivil_03/leis/L4024.htm. Acesso em: jan. 2020. 
CUNHA, Luiz Antônio. A Luta pela Ética no Ensino Fundamental: religiosa ou laica? 1.

Cadernos de Pesquisa, Rio de Janeiro, v. 39, n. 137, p.401-419, ago. 2009.

CUNHA, Luiz Antônio; GOÉS, Moacyr de. O Golpe na Educação. 7. ed. Rio de Janeiro: J.Z.E., 1991.

CURY, Carlos Roberto Jamil. Ideologia e Educação: Católicos e Liberais. 3. ed. São Paulo: Cortez, 1986.

CURY, Carlos Roberto Jamil. Ensino religioso na escola pública: o retorno de uma polêmica recorrente. Revista Brasileira de Educação, Minas Gerais, n. 27, p.183-213, dez. 2004.

DERISSO, José Luis. O Ensino Religioso na Escola Pública e a Epistemologia dos materiais implementados nas escolas oficiais do estado de São Paulo após a Lei n.9475/97. Orientadora: Marisa Bittar. 2006. 128 f. Dissertação (Mestrado) - Curso de Pósgraduação em Educação, Universidade Federal de São Carlos, São Carlos, 2006. Disponível em: https://repositorio.ufscar.br/handle/ufscar/2412. Acesso em: jan. 2020.

PAULO VI, Papa. Declaração gravissimum educationis: sobre a educação cristã. Roma, 1965. Disponível em:

http://www.vatican.va/archive/hist_councils/ii_vatican_council/documents/vatii_decl_19651028_gravissimum-educationis_po.html. Acesso em: 30 out. 2019.

PIO XI, Papa. Carta-Encíclica Divini Illius Magistri. Roma, 1929. Disponível em:https://w2.vatican.va/content/pius-xi/pt/encyclicals/documents/hf_pxi_enc_31121929_divini-illius-magistri.html. Acesso em: 09 abr. 2019.

SAVIANI, Demerval. Política e Educação no Brasil. 6. ed. Campinas: Autores Associados, 2006.

SCHERER, Vicente, Arcebispo. Memorial dos bispos gaúchos ao Presidente da República sobre a Escola Pública Única. Vozes, Petrópolis, v. 52, maio 1958. Disponível em: http://www.bvanisioteixeira.ufba.br/artigos/bispo.htm. Acesso em: 23 out. 2019.

\section{Como referenciar este artigo}

BUCHOLZ, Luize Gomes; DERISSO, José Luis. O ensino religioso nas leis de diretrizes e bases da educação nacional e os embates entre religiosos e laicos no Brasil. Revista IberoAmericana de Estudos em Educação, Araraquara, v. 15, n. 2, p. 667-681, abr./jun. 2020. eISSN: 1982-5587. DOI: https://doi.org/10.21723/riaee.v15i2.13516

Submetido em: 20/01/2019

Revisões requeridas: 03/07/2019

Aprovado em: 24/10/2019

Publicado em: 20/02/2020 